\title{
China struggles to square growth and emissions
}

China this week postponed its scheduled release of a national plan to deal with climate change. But observers say the move is not so much a delay in dealing with the issue as an indication that the Chinese government is taking climate change more seriously — and that this is as much to protect its own needs as it is a response to international pressures.

China's booming economy - it grew by $11 \%$ in the first quarter of 2007 - has long worried those trying to control the rise of greenhouse gases in the atmosphere. And estimates made public last week back up that concern: they suggest that China will exceed the United States as the biggest emitter of greenhouse gases as early as the end of this year - not 2010, as energy experts had previously forecast.

With a new coal power plant being built there roughly every four days, China's emissions are undoubtedly soaring. The question is by how much. A report released by Greenpeace on 24 April says that under a "business as usual" scenario, they will triple by 2050 . But compared with the United States, China's per capita emissions are still quite low: in 2003, China emitted 3.2 tonnes of carbon dioxide per person, whereas the United States emitted 20 tonnes per person.

The Chinese government has consistently argued that it cannot put caps on greenhousegas emissions while the country is still developing. But the United States has refused to join any international regulatory framework on climate change, such as the Kyoto Protocol, unless limits for developing countries are also included.

China's climate-change plan, which had been set for release on 24 April, has now been put off until next month. But urgent action seems essential. A national assessment released in January paints a grim picture for the country's future. It notes that over the past few years there has been a $12 \%$ drop in water supply to northern China. Without significant measures to combat global warming, the report predicts that the productivity of China's three staple crops - rice, wheat and maize (corn) - will fall $5-10 \%$ by 2030 , and will be close to $40 \%$ by the second half of the century.

Such specific predictions are spurring the government to act after many years of inaction, says Yang Ailun, a Beijing-based environmental expert with Greenpeace. "Before, China always relied on the same arguments about the historical responsibility of developed countries," she says. "That makes sense. But now China is greatly concerned about its vulnerability and social stability."

China is already committed to reining in increases in energy use, and such efforts are closely linked to the country's ability to limit emissions. It plans to close down 50 gigawatts' worth of its least-efficient power plants by 2010. That would mean shutting down roughly 1,000 small plants. "If the small, old plants are there, there is no way to decrease energy consumption," says Yang Fuqiang, a Beijing-based energy expert with the Energy Foundation.

These efficiency initiatives are part of the country's Five Year Plan for National Economic Development for 2006-2010, which calls for a reduction in the amount of energy spent to produce a unit of gross domestic product by $20 \%$ within five years. "The targets are tough, but they are possible," says the Energy Foundation's Yang.

Energy-efficiency targets have, however, become a sore point. The first year of this plan fell far short, achieving only a $1.23 \%$ drop according to government figures. And so far, signs for 2007 are not good, says James Brock, an independent energy adviser in Beijing.

Brock has advised both the UK and US chambers of commerce on Chinese energy issues. He says he has witnessed the tension in meetings at which officials from the National Development and Reform Commission, which recommended the $20 \%$ target, suggested to the powerful State Council that the target can't be met and should be recalculated. "They got read the riot act," says Brock.

Part of the problem is the difficulty in measuring emissions precisely. These are generally estimated on the basis of the types and amounts of energy consumed. But remote-sensing studies of nitrogen dioxide concentrations - which are also released during the burning of fossil fuels - suggest that estimates based on energy consumption could be too low (H. Akimoto et al. Atmos. Environ. 40, 7663-7667; 2006, and A. Richter et al. Nature 437, 129-132; 2005).

Hajime Akimoto of the Frontier Research

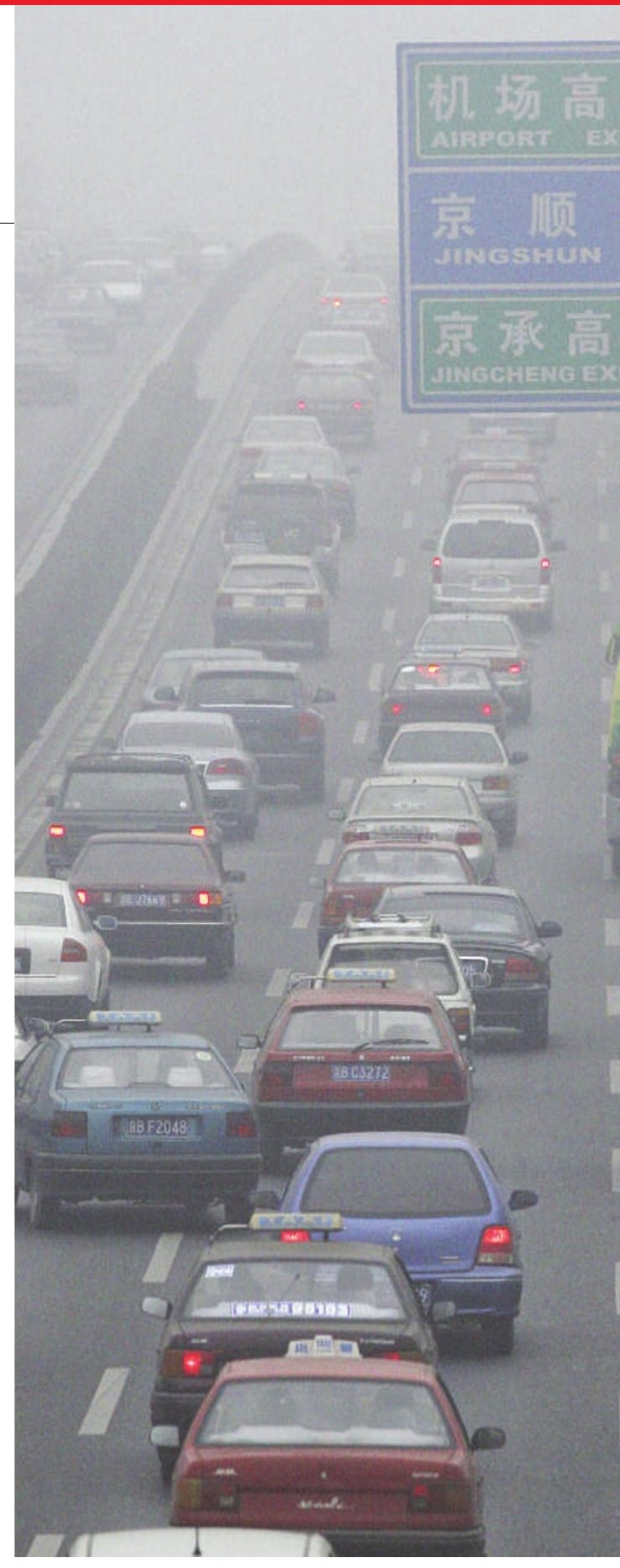

Predictions for China's emissions of carbon dioxide could be underestimated by $15-20 \%$.

Center for Global Change in Yokohama, Japan, says the satellite data show a $50 \%$ increase in nitrogen dioxide concentrations between 1996 and 2002. This compares with a $15 \%$ increase calculated by the International Energy Agency based on energy consumption over that period.

Indeed, experts say the uncertainty is so great that it is difficult to know how China's carbon emissions compare with those of the United States. Gregg Marland, an environmental scientist at Oak Ridge National Laboratory in Tennessee, says that crucial figures needed to estimate China's energy consumption are often missing. Changes in remaining stocks of coal go 


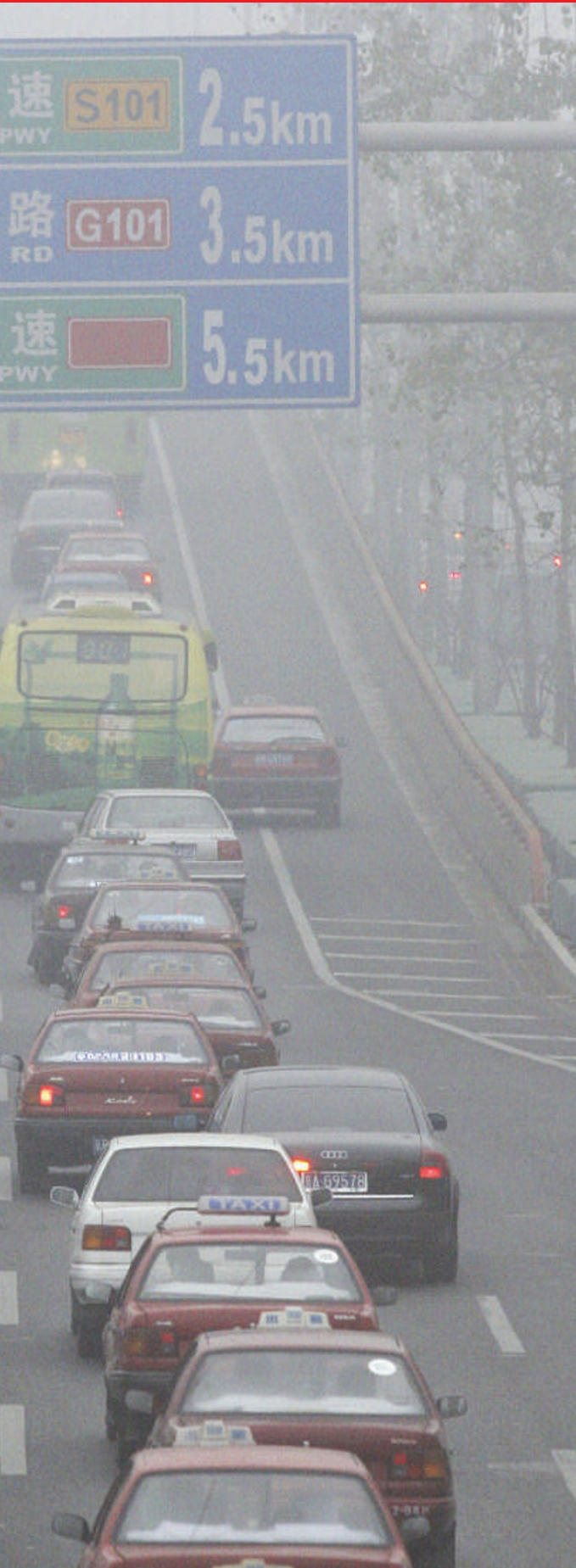

unreported, for example, or, for a single year, a figure will inexplicably drop to zero. Marland says that, as a result, any estimates of China's emissions could be off by $15-20 \%$.

$\mathrm{He}$ adds that the considerable amount of carbon dioxide produced in making cement, if included in the figures, could also tip the balance. China produces $45 \%$ of the world's cement. "China could be exceeding the United States right now," Marland says.

Further details of China's carbon dioxide emissions may have to wait until next year, when NASA plans to launch the Orbiting Carbon Observatory. The satellite is designed to provide high-resolution data on worldwide carbon dioxide emissions. David Cyranoski

See Editorial, page 949

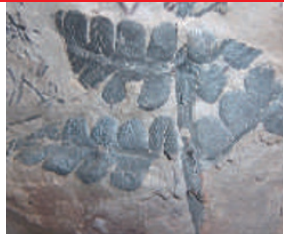

FOSSILFOREST

Extinct species found in coal mine.

www.nature.com/news

\section{Primate work faces German veto}

German scientists have condemned a parliamentary decision to stop primate experiments at the University of Bremen, calling it unacceptable political interference with the freedom to conduct research.

Animal-rights activists in the state of Bremen have been campaigning for years against the macaque experiments of Andreas Kreiter, a neuroscientist at the university's brain research centre. Now, in the run-up to regional elections on 13 May, the activists have finally won cross-party political support.

Bremen's parliament last month unanimously asked the state government not to reapprove Kreiter's experiments from the end of 2008, when his licence becomes due for renewal. Meanwhile, a commission of scientists and representatives of animal-protection groups is to re-evaluate the scientific value of Kreiter's research, and assess whether the experiments could be replaced by non-invasive methods. Both issues have been addressed before by granting agencies and by the local authorities and ethics committees, Kreiter says.

Neither the state parliament nor the state government can order the university to close down the centre. But Kreiter fears that political pressure will force the local authorities not to approve further experiments.

"This decision was motivated by the election campaign," says Matthias Kleiner, president of the DFG, Germany's main funding agency for university research. "It's an attempt to interfere with the constitutionally guaranteed freedom to research. We hope that the approval authorities in charge will decide solely on the basis of applicable law."

Primate researchers in Germany are used to violent protests. Kreiter's research, on cognitive processes such as attention, involves placing electrodes in monkeys' brains. $\mathrm{He}$ and his family were put under police protection in 1997 after they received threatening letters. Attacks have since ceased, but in March animal campaigners submitted to Bremen's parliament 15,000

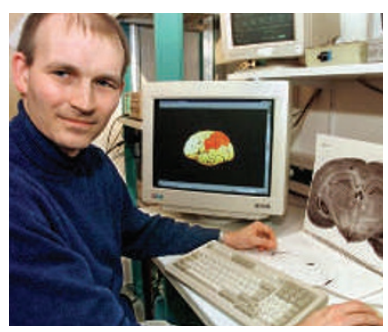

"It seems weird that the same people who have fought me to the finish will now judge my work."

- Andreas Kreiter

signatures from people who opposed the experiments.

Considering the ethical pros and cons of animal experiments is always crucial, says Alexander Thiele, a brain researcher at Newcastle University, UK. But he says that the level of political interference with Kreiter's project, which has been approved both legally and ethically, is "scandalous".

Thiele had been offered a professorship at the Humboldt University in Berlin, which he rejected when local authorities last week denied approval for his planned experiments on visual attention in macaques. He says that such blatant political intervention at a local level is less common in Britain because experiments there are approved by the Home Office.

The state science ministry in Bremen, which oversees the university, is also unhappy with the parliamentary decision. "This is very disturbing," says Holger Bienhold, a ministry official in charge of the natural sciences. "It's hardly conceivable to stop a professor from doing legally and ethically approved research."

Kreiter has won around $€ 3$ million (US\$4 million) in grant money from various sources, including the DFG, the federal science ministry, and the European Union.

Kreiter is determined to continue his research in Bremen, and has started to prepare for possible lengthy lawsuits. The commission is due to release its review of his work is due in June. "It seems weird to me that the same people who have fought me to the finish will now judge my work," he says. "They will most likely misuse every bit of information they can get."

But the experiments are cruel to animals, says Wolfgang Apel, president of the German Animal Welfare Association and organizer of the petition against Kreiter's work. The committee, he says, will suggest how, and not just whether, the experiments will be phased out.

Alternatives to some types of invasive experiments on primates do exist. For example, functional magnetic resonance imaging can effectively measure activity in large groups of brain cells. But to measure the activity of individual neurons, which is crucial to study cognitive processes such as visual attention, electrodes must be directly inserted into a monkey's brain.

Quirin Schiermeier 